\title{
THE ALTERNATIVE ISLAMIC PRICING BASED ON NATURE OF BUSINESS
}

\author{
Rachmawaty \\ Pamulang University, Jakarta, Indonesia \\ Email : Dosen01925@unpam.ac.id
}

Abdurrachim Saie

Tazkia Institute, Bogor Indonesia

Submitted: 14-04-2020 | Reviewed: 16-05-2020 | Published: 10-07-2020

\begin{abstract}
The contradictive of using interest rate as Islamic Pricing Benchmark (IPB) has been discussed among scholars. A lot of alternatives has been offer by scholars but the implementation is based on market choices which are the competitive pricing of interest rate and the advantage of majority share of conventional financing. In this paper there will be 3 objectives; first to give information of literatures review for some alternatives that already offer by scholars, second is to give information about pro and cons of using interest rates as the benchmark of cost of fund for Islamic Financial Institutions and the final objective is what author's opinion and what kind alternative that author will provide based on literature review and author's logic sense.

The alternative IPB will be explained in this paper is based on nature of business, which will be categorized as IPB for debt financing, equity financing and combine financing. To implement IPB there are some infrastructure that will need to adjust in order to create fair environment such as educate customer and change the behaviour of customer to choose financing product, to change the role of bank and to see the paradigm of cost of statuary reserve requirement in central bank.
\end{abstract}

Keywords : Islamic Pricing Benchmark, interest rate, debt financing, equity financing, financing product

\section{A. INTRODUCTION}

Avoiding riba in transaction, is absolutely prohibited in sharia rules, a lot of process and financial products was designated to riba or haram things and to make them suitable with the concept of aqad. However, there are still debate among scholars and practitioner how to define the cost of capital in financial transactions. Some of the reasons of using conventional bank's interest rate as benchmark in almost transactions in Islamic Financial Institutions (IFI) was because first, IFIs are the part of Conventional Financial and the market share of IFI is less than $1 \%$ in total international transaction, secondly Conventional Financial International (CFI) journey and existence is much older and stable compare with IFI, and third, there is no exact guideline in Hadist how to determine profit, the only information that it is allowed to take profit. The fourth one is, economic law, people will choose theproduct with the highest profit for their asset to invest or utilize and will want the cheapest cost if they one to lend or to get financing. 
It is a needy to do research with objective of making IPB that can show justices of Islamic Financial and to avoid the impact of the dangerous of wrong calculation of taking excessive profit and unfair treatment to another parties in financial transactions. A lot of research and workshop has been done by scholar in order to find the new alternative of profit rate or cost of capital as the model of IPB. Some of the model was implemented and some of them are still in idea, but most of IFI included regulator in majority Muslim countries still use interest rate as the benchmark to calculate cost of capital or profit.

\section{B. LITERATURE REVIEW}

Much criticism has been address against Islamic banking and finance for depending on the conventional benchmark. Many contemporary Muslim scholars have been calling forinitiation of an independent benchmark pricing for Islamic banks. Some of idea was summarize in this article such as how to calculate cost of capital and Investment in a Non-interest Economy using Tobin's q (Mirakhor, 1996), Rate of Profit Mechanism Model (Al Ghazali, 1414 AH) and Creation of an Inter-Islamic-Banks Market Based on Islamic Principles (Shaykh Muhammad TaqiUsmani, 2007)

Abbas Mirakhor (1996) suggests a procedure by which the cost of capital can be measured in the absence of a market rate of interest. The suggested procedure utilizes Tobin's q in calculating the cost of capital in an economy where debt instruments have been removed. In the absence of a fixed and predetermined rate of interest, equity financing becomes the only source of financial capital, and as such, the economy's financial system becomes equity-based. The q theory of investment, which relates investment to the ratio of market to replacement value of capital, has attracted considerable attention. Yoshikawa (1980), Summers (1981), and Hayashi (1982) show that under certain conditions the rate of investment of a share value -maximizing firm is a function of $q$. Marginal $\mathrm{q}$ is the ratio of the market value of an additional unit of capital to its replacement cost. Based on a cash flow model in which the firm faces convex costs in adjusting its capital stock, it has been shown that physical investment is determined by marginal q, defined as the ratio of the discounted future revenues from an additional unit of capital (i.e., the shadow price of capital) to its net-of-tax purchase price (Mussa (1977), Abel (1979)). Critical to the operational usefulness of this model is that unobservable marginal q must be related to observable average $\mathrm{q}$, defined as the ratio of financial to physical capital. The conditions under which this connection can be drawn have been established in Hayashi (1982).

Rate of profit mechanism model was proposed by Abd al-Hamid al Ghazali, (1414 AH).77 According to him, this can be achieved by analyzing the rate of profits in the money market. He proposes that it is a more rational way that promotes justice for all and fits the nature of economics. But this model has been criticized. Hussain Hassan Shahatah stated, "There will be a problem in defining the concept of profit and its scope: whether the expected profit will be from each project, or from a group of projects involved in a specified activity, or from a group of projects that involve various activities.

The Creation of an Inter-Islamic-Banks Market Based on Islamic Principles, was suggested by Shaykh Muhammad Taqi Usmani (2007). According to him, the purpose can be achieved by creating a common pool which invests in asset backed instruments like musharakah, ijarah, etc. If the majority of 
the asset pool is in tangible form, like leased property or equipment, shares in business concerns, etc., its units can be sold and purchased on the basis of their net asset value determined on a periodic basis. These units may be negotiable and may be used for overnight financing as well. Banks having surplus liquidity can purchase these units, and when they need liquidity they can sell them. This arrangement may create an interbank market, and the value of the units may serve as an indicator for determining the profit in murabahah and leasing also.

\section{DISCUSSION}

Scope of discussion that will be explore in this article are to understand the validity of concept of time value of money in Islamic's view, second to understand the components and considerations of in determining the pricing of asset or services, third is the alternatives of IPB that some scholars offered and how it is implementation of Interest rate benchmark and the last one is the pro and cons of using interest rate as the benchmark for Islamic Financial transactions.

\section{C.1 Time Value of Money}

Before discussing about IPB, it is important as basic concept to understand whether Islam allowed the increasing of price in one commodity in deferred payment. Based on haditsand scholars explanation, it is allowed to increase the price of commodity because of deferred payment.

"The fact that Islam forbids riba it does not mean It is against the concept of positive time preference (PTP). Islam recognizes PTP as reflected in one of hadits The Prophet (pbuh) said," Virtuous are they who pay back their debts well." Some reasons why Islam enjoins people to pay their debts well, for showing gratitude of debtor to the one who lend money. Debtor knows that creditor has possibility to reduce his current consumption because their money was lent by debtors, secondly is the possibility of fail to earn returns from loan given away, these returns are unknown as business risk but the incremental amount is not stated up front. (Rosly, 2014)

In financial transaction, price of credit sale is higher than on the spot basis was accepted because the increment due to there is delayed payment, which impact to risk associate for long time and potential loss for usufruct of commodity or money at that time for the ones who has commodity. Increasing the price due to delayed payment is allowed because the increasing is against commodity not the money.

\section{C.2 Element of Cost of Pricing for Financing/ Lending}

Cost of pricing for bank to lend or finance basically consider with the cost of fund, cost of bank itself to operate, and the risk or other cost that bank will bear. Element of cost of fund as the basis to calculate interest rate or profit rate.

According explanation in Islamic Banking Practises courses, in Malaysia to calculate Base Lending Rate (BLR) of conventional banking consist of elements KLIBOR + Statuary Regulatory Reserve + Cost of Operation + Spread. While in Islamic Banking, the calculation of Base Financing Rate (BFR) is the same, except KLIBOR has been change to average of 3 month return rate of General Investment Account in that particular bank. Using this formula, conventional refers to KLIBOR which is the cost of fund in Inter Money Market, while Islamic Bank refers to the average of performance of their 
investment account which is if Investment Account of Islamic Bank is good than the price of BFR will be increased and will not competitive anymore.

\section{C.3 Capital Asset Pricing Model (CAPM)}

The basic reason why CAPM is considered to be one of model in determining cost of fund, because Islamic transaction dealing with asset as underlying transaction or economic activities as one of the object financing. It is fair enough for investor to get at least the same value of asset included money as wealth that they invest to. In this correlation investor who save money in Bank, and bank as the manager who manage the money will calculate money as "commodity" compare to value of asset. Even thought to calculate CAPM is still under debatable by scholar, because there is element of fixed interest.

CAPM is a model to calculated required rate of return of an asset, it is consist of risk free rate (rf), the minimum requirement rate to invest and associate with time value of money, usually it is compared to yield of government bond. Beta $(\beta)$ is the factor of comparison to market portfolio asset and risk premium as additional risk. Since this is fixed rate like interest rate, and in Islam interest rate is forbidden. In the absence of risk free asset, than it means the $r s$ (requirement of return) is a performance of return asset compare to market.

But, there are some theory according Saadafet.al(2014) which I thought it is make sense to ignore of the fixed return in risk free and change it with the highest of this 2 result of following theory:

1) The risk free return could be replace with $2,5 \%$ (nominal of zakat), since it is the minimum nominal for investor to invest is at least they can cover their zakat. (Ashker, 1987).

2) The risk free return could be replace with inflation rate, since it is Government's obligation tomaintain of citizen's wealth and to protect the purchasing power compare to inflation rate(Hanif, 2011)

Other theory was stated, the risk free could be replace by GDP, Sheikh (2010), or ignore the risk free and converted $\square$ to other factor of rate of return, Cyril \&Ri'fat (1987).

\section{C.4 Alternatives of Islamic Pricing Benchmark}

The idea to use rate of profit as IPB to create equitable distribution income between those who has money and those who need fund. The next questions then, how to calculate rate of profit that can meet shariah concept and industries in practises.

Some alternative to calculate profit rate as IPB that has been offer by scholars was summarize as follows included the critique from other scholars and my opinions base on logic sense:

\section{Using rate of dividend of Islamic Bank deposits \& Investment Account.}

The model was introduced by Muhammad Abdul Umar, 2009. In his model, he suggested to use dividend that Islamic Bank distributed to its customer. This model has some critiques since the model is just change the terminology of interest rate to become profit rate.

In my opinions, by using this model there is no standard benchmark since among Islamic bank has their own policy to distribute dividend or dividend could be not direct related with the profit of project for example some profit for capital investment and will not distributed as dividend, there will a lot of variety of rate of dividend depend on the performance of project. The better performance of 
project will give more dividend and the impact to the cost of fund then it will not good for pricing competition.

2. Using of average sharia Islamic sukuk (bonds), with the price is mark to market.

The profit rate for Islamic asset in the market can refers to financial asset such as sharia Islamic bonds (sukuk) Supriyanto, Trisiladi 2016. The return of sukuk is quite stable and not volatile.

There is a critique for this model, since one of the element of return of sukukare risk free that are benchmark to fixed rate of government bond which is refers to interes rate as well (see explanation on CAPM above). Besides it, in my opinion there are a lot of sukuk, which sukuk and what the criteria sukuk that will be use as benchmark, is it on country base on industrial base? There is no clear explanation about it.

3. Using Market rates, such as Consumer Pricing Index or Business Price Index or a mix

There is idea also to proposed that other rates, CPI or Business Price Index or a mix of the two, as the basis to determine the profit rate. CPI or Business Price as benchmark can be used for both bank (Islamic and Conventional) as the real price. The CPI or Business Price is suitable for prediction of sale transaction or debt financing such as murabaha but it is need more research as comparison for the benchmark of equity financing such as musyarakah/mudharabah or leasing contract such as ijarah.

4. Using Rental Rate for MusharakahMuntanaqisah Partnership

Rental rate can reflect the mortgage value in the market, based on research done by Ali, Rama cs (International Islamic University Malaysia) it shows the positive correlation between the rental rent and interest rate. The rental rate will be different in every area and for different type of housing/apartment.

\section{Creation an Inter-Islamic-Banks Market}

According to Usmani, Muhammad Taqi (2007), the purpose to create Inter- Islamic banks market based on Islamic principle to create a common pool for asset backed instruments for Islamic product such as musyarakah, ijarah, mudharabah. The concepts is the commodity of unit can be sold and purchased on the basis of their net asset value determined on a periodic basis. The price of units can be negotiable and may be used for overnight financing as well.

The function of inter bank as the system for bank to manage its liquidation such as bank who has more money (liquidity) can purchase these units and when its need more fund then bank can sell those units. The value of the units will be use an indicator for determining the profit in Islamic products.

\section{C.5 Pro and Cons Using Interest Rate Benchmark}

Example of grad scholar whom show agreement to use interest rate as benchmark is not haram but discourage using it, Shaykh Muhammad TaqiUsmani advocates that Islamic banks and financial institutions should get rid of the interest-based benchmark as soon as possible. He argues that using an interest rate as a benchmark for a Halal business is undesirable and does not advance the basic philosophy of Islamic economy, thereby making no impact on the system of distribution. But ShaykhUsmani also quoted that merely using the interest rate as a benchmark for determining profit of murabaha does not 
render the transaction invalid, haram or prohibited because the deal itself does not contain interest. The rate of interest has been used only as an indicator or as a benchmark.

There are some scholar doesn't agree to use interest rate as bench mark for Islamic pricing. The reason of rejected by scholars that summarize by Supriyanto, Trisiladi 2016 as follows:

a. Profit rate was determination by using methodology of mark to the market and real market index (Rahman, Yahia Abdul. In The Art of Islamic Banking and Finance: Tools and Techniques for Community Based)

b. Profit rate can be determination by rate of return in real market (Khan, Mohsin S. The Financial System and Monetary Policy in an Islamic Economy)

\section{PROPOSAL TO DERTERMINE PRICING RATE OF ISLAMIC FINANCING PRODUCT}

In order to determine pricing rate as the IPB, I would like to explain 3 points as the key driven of pricing benchmark. First is the nature business of Islamic financing, what kind of contract and the impact of it in asset and profit, second is factors that can influence people as the power of market to choose and use a pricing benchmark, third is my proposal as the alternative of Islamic Pricing Benchmark for financing product.

\section{Nature business of Islamic Financing Product}

Nature business of Islamic Financing product to understand the risk that will bank face and it will determine the price that bank should face (the concept higher risk higher price).

There are 2 kind of Islamic financing; debt financing and equity financing. In debt financing such as Murabaha, Tawaruq and Ijarah; In this transaction, bank face business risk because bank take position as the one who own the asset and record it in its books until the asset transfer to other parties. In equity financing such as Musyarakah and Mudharabah, Bank doesn't face business risk and only financial risk (credit risk, operational risk and market risk). Based on that explanation for debt financing is consist of business risk and financial risk, while equity financing has only financial risk. In conventional banking the risk that bank face is only financial risk which is equivalent with equity financing in Islamic bank. In equity financing, Islamic pricing benchmark to interest rate is acceptable because the similarity of nature of business.

In this model, it shows that debt financing like murabaha since Islamic Bank has the ownership which is riskier if we applied risk concept can impact to the higher pricing. In my opinion the concept of risk based on pricing can not be applied 100\% in Islamic Transaction since the price will not competitive to conventional bank. The concept can be applied if bank should change the concept not as the one who has asset, but just as agent/ wakil between the owner asset and debtor. But if the contract if still using ijarah and murabaha (MusharakahMuntanaqisah), the pricing that bank should refer to rental pricing in the area and combining with Housing Index Price as the price to redeem share.

Tabel 1. Model of Risk 


\begin{tabular}{|c|c|c|c|}
\hline \multicolumn{2}{|c|}{ Islamic Financing } & Conventional Loans & \multirow{3}{*}{$\begin{array}{l}\text { Proposal : } \\
\text { Debt Financing: } \\
\text { Fee as agent, Bank change role just as } \\
\text { agent, the asset belong to other party, } \\
\text { pricing between party and customer is } \\
\text { rental payment + redeem share. } \\
\text { Equity Financing: } \\
\text { Pricing can should be competitive as } \\
\text { Interest rate, or use CAPM Model } \\
\text { which one is lower. }\end{array}$} \\
\hline $\begin{array}{l}\text { Debt } \\
\text { Financing: } \\
\text { Murabaha, } \\
\text { Ijarah, }\end{array}$ & $\begin{array}{l}\text { Business } \\
\text { Risk } \\
\text { Financial } \\
\text { Risk }\end{array}$ & \multirow{2}{*}{$\begin{array}{l}\text { Loan : } \\
\text { Financial Risk }\end{array}$} & \\
\hline $\begin{array}{l}\text { Equity } \\
\text { Financing: } \\
\text { Musharakah } \\
\& M u d h a r a b \\
\text { ah }\end{array}$ & $\begin{array}{l}\text { Financial } \\
\text { Risk }\end{array}$ & & \\
\hline
\end{tabular}

\section{Power of Market to Choose Benchmark Pricing}

Human as the one who drive the market as general has 2 characteristics, those are economic decision base and Sharia/Believers decision base. For economic decision base, absolutely the benchmark should the best price for them, if the funding rate then the rate should be highest one and if the borrowing one should be the cheapest one. Here is the market competition will take apply unless there is interfere from government. It is important to realize even in Muslim Country like Malaysia who support Islamic Financing still benchmark to Interest rate because if the price is not competitive, the money from Malaysia will transfer to other country who can give more competitive price and it will give impact to Malaysia economic growth and inflation. The behaviour of Sharia decision will be different like in Kelantan, who will not take the priority of pricing. In this segment of market, Islamic Financing can price as the real risk and the nature of business.

3. Element should consider as the Islamic Pricing benchmark

The concept of taking element of pricing, based on the understanding of CAPM and the formula of BFR. The formula of BFR is average dividend of GIA + SRR+ Overhead Cost + Spread. Some critics for using BFR with reference of average 3month of dividend GIA for bank who has good projects financing will give impact the higher pricing compare with others bank, and the good customer who has project will tend to choose conventional bank who has cheaper price. As the impact those who apply for debtor in Mudharabah/ Musyarakah are not the good project. BFR also can not for all financing, the nature of business of financing should be the main factor to driven what kind of pricing will be applied.

BFR should be implemented just for debt Financing where the price is should be consider with Consumer Pricing Index the Country as the basis cost of commodity and the profit or spread is compensation of inflation and zakat. For equity financing, there is no need BFR since the nature of business is profit sharing that customers should take consider it.For Ijarah, the BFR should refers to rental rent in that particular area plus spread of compensantion of inflation and zakat.

The complex ones if for financing consist of more than one aqad like MusharakahMuntanaqisah (Murabaha plus Ijarah) and Tawaruq (Wakil plus Murabaha), for this financing the pricing refers to 
combining of the market such as MusharakahMuntanaqisah is rental payment plus redeem of Consumer Pricing Index (housing pricing index).

With the risk that already cover, to avoid overpricing that can make Islamic Bank will not competitive with conventional banking, it is not necessary to add SRR (statuary reserve requirement) as the Basel suggested to all country. In this model we should different model with conventional otherwise the price of Islamic Financing will be more expensive. The Role of Bank also should change from now that a lot of debt financing to be more equity financing which is real economy activities.

\section{E. CONCLUSION}

Since market share Islamic Financing in the world just $1 \%$, and also in Malaysia is just $26 \%$, in Indonesia is $5 \%$, which is lower than Muslim population is $28.6 \%$ (Worldbank.data.com). it is logic the conventional bank methode will take lead and control since it is the majority (99\%) but if all Muslim can be educated and change the behaviour to choose financing not just for economic reasons but also for blessing of Allah then IPB and Inter Bank Islamic Market can be effective.

IPB that I proposed consider to the nature of business of aqad but should still consider with the competitive pricing of conventional until inter bank Islamic market internationally created otherwise it will difficult for Islamic banking to get fund or to financing.

The summary of IPB that I proposed and the support infrastructures as follow :

\section{Debt Financing:}

Consumer Pricing Index + Inflation Prediction + Zakat

\section{Equity Financing:}

Non BFR, the pricing should real on profit sharing of project

Combine Financing (Equity + Ijarah/ Wakil):

Rental Rent of Ijarah + redeem share based on Consumer Pricing Index (Housing Pricing Index)

Support by:

Change Role of Bank : More Equity Financing and more do as Wakill, rather than give debt financing.

Change Risk Management philosophy for idle money in Statuary Reserve Requirement, for Islamic Banking, no need SRR because the risk already cover and risk sharing. For Risk protection, do TAKAFUL which the premium could be lower than cost of idle money of SRR.

Educate Customer, specially Muslim customer so the behaviour can change to customer whose has characteristic Sharia Customer not Economic Customer.

\section{REFERENCES}


[1] Abbas Mirakhor, Cost of Capital and Investment in a Non-Interest Economy, Islamic Economic Studies Vol. 4, No. 1, December 1996.

[2] Abel, Andrew B. (1979), Investment and the value of capital, New York: Garland.

[3] Abd al-Hamid al Ghazali, Al-Arbahwa al-Fawaid al-MaÎrafiyyahBayna al-IqrisadiwaHukm alShariah, Jeddah: Islamic Development Bank, 1414 AH

[4] Ali Rama, Wisnu Wardhana, Faried Kurnia Rahman, Ilham Reza Ferdian. Islamic benchmarking: an alternative to interest rate, University International Islamic Malaya.

[5] Hayashi, Fumio (1982), “Tobin’s marginal q and average q”, Econometrica, Vol. 50

[6] Islamic Pricing Benchmark, Riset Paper ISRA no. 17/2010

[7] Muhammad Abd al-Alim Umar \& Muhammad FathiShatah; quoted from Shehata, IjadMu'ashshir, Cairo: University of al-Azhar Book Centre, College of Commerce.

[8] Saadaf, Rabeea\&Samer, Adleeb. (2014). Journal in Banking\& Islamic Finance , March 2014vol 2, Islamic Capital Asset Pricing Model (ICAPM)

[9] Saiful, Azhar Rosly (2005).Critical Issues on Islamic Banking and Financial Markets.Dinamas Publishing, Kuala Lumpur.

[10] Summers, Lawrence H. (1981), "Taxation and corporate investment: A q-theory approach", Brookings Papers on Economic Activity

[11] Trisiladi Supriyanto, The Role of the Rate of Profit Concept in Creating Islamic Financial Market Stability, 2016

[12] Tobin, J. (1969), “A General Equilibrium Approach to Monetary Theory”, Journal of Money Credit and Banking, Vol. 1, February

[13] Usmani, Muhammad Taqi. (2007). An Introduction to Islamic Finance. Pakistan: Quranic Studies Publishers.

[14] Yoshikawa, Hiroshi (1980), “On q Theory of Investment”, American Economic Review, Vol. 70, No. 4 